\title{
PROBLEMS RELATED TO THE PRESERVATION OF THE IMMOVABLE CULTURAL HERITAGE OF BULGARIA
}

\author{
Milena Ivanova $^{1 *}$ And Olga Kovalevskaya ${ }^{2}$ \\ ${ }^{1}$ University of Economics - Varna, \\ 77, Knyaz Boris I Blvd, 9002 Varna, \\ e-mail: milena_ivanowa@ue-varna.bg \\ ${ }^{2}$ Saint Petersburg State University of Economics, \\ Saint Petersburg Supervision channel Griboyedov, \\ 30-32, letter A 191023, Saint Petersburg, \\ e-mail:kovalevskaya05@mail.ru
}

\begin{abstract}
The article presents some problems of the protection of the immovable cultural heritage in Bulgaria. The solution of the problems will help for both saving the physical authenticity of the immovable cultural properties but also for a sustainable urban development and a new possibility for the development of cultural tourism.

Keywords: cultural heritage, cultural tourism, immovable cultural heritage.
\end{abstract}

\section{INTRODUCTION}

Bulgaria is the successor to the cultural and historical heritage of the seven civilizations and is ranked as the third in Europe - after Greece and Italy - in respect and variety of immovable monuments of the culture. Many of the Bulgarian cities have a specific look, a work of architecture, building, engineering and sculpting craftsmen who have built the walls in the period of the XIX$\mathrm{XX}$ centuries. This is a resource located on almost the overall territory of the country, which includes seven cultural and natural objects in the UNESCO List of cultural and natural heritage and about 40,000 registers of Immovable Cultural Values (ICV), with about 19,400 thereof being for architectural construction. This resource is not only a reason of pride itself, but a challenge and a responsibility. The same point of view is incorporated in the Convention for the Protection of the Architectural Heritage in Europe - Grenada [1], in which

${ }^{*}$ Corresponding author.

DOI: 10.7546/EngSci.LVIII.21.04.02

Engineering Sciences, LVIII, 2021, No. 4 
it is stated that the architectural heritage is indispensable evidence because of the wealth and diversity of the cultural heritage and common welfare for all Europeans.

The aim of the authors of the article is to study some of the problems of preserving the immovable cultural heritage of Bulgaria in order to support the theory and practice in this area.

\section{NATURE AND SIGNIFICANCE OF THE IMMOVABLE CULTURAL HERITAGE}

The term "cultural heritage" was first introduced as a common term in 1954 in the UNESCO Convention [2] and in the European Cultural Convention of the Council of Europe [3]. According to the Cultural Heritage Act [4] the immovable cultural heritage covers cultural values that are permanently attached to the ground, including underwater, as well as their surrounding environment. For the purposes of the study, the authors adhere to the definition given in the International Charter for the Conservation and Restoration of Monuments and Sites [5], also known as the Venice Charter: "the term cultural monument includes not only the individual architectural work, but also the urban and rural ensemble, which contains evidence of a particular civilization, a remarkable evolutionary process or a given historical event. This concept includes not only the great, but also the more modest creations, which over time have acquired cultural significance".

The significance of the immovable cultural heritage is determined by the following reasons:

1. The immovable cultural heritage is a public good, which largely determines the specific appearance of a settlement.

2. The immovable cultural heritage is a long-term asset that is a factor in the development of tourism and in particular - cultural tourism. The Strategic Plan for the Development of Cultural Tourism states that cultural tourism is able to contribute to increasing investment in the region, creating jobs and increasing employment, increasing incomes realized on the basis of increasing the number of tourists, increasing the social welfare of the population, which has no monetary value [6]. The draft "Update of the National Concept for Spatial Development 2013-2025" states that the valorization of cultural and natural heritage through inclusion in tourism products is one of the local, regional and national resources with still untapped potential $[7]$. 
3. The Conclusion of the Council of 21 May 2014 on cultural heritage as a strategic resource for a sustainable Europe states that cultural heritage (including the immovable - author's remark) plays a special role in achieving the objectives of the strategy [8]. "Europe 2020 for smart, sustainable and inclusive growth" as it has a social and economic impact.

4. The cultural heritage, including real estate, is important for the European economy. According to Eurobarometer data, more than 300,000 people are employed in the cultural heritage sector, and more than 7.8 million jobs are indirectly related to it. To each job that is directly related to the sector, about 26 indirectly related jobs are added (e.g. from the Construction and Tourism sectors).

5. The importance of cultural heritage is recognized by the European community and 2018 has been declared the European Year of Cultural Heritage. The aim of the European Year of Cultural Heritage is to encourage more people to discover and study European cultural heritage, as well as to strengthen Europeans' sense of belonging to the common European family. The emphasis is on the value of cultural heritage to society, its contribution to the economy, its role in European cultural diplomacy and the importance of its preservation for future generations.

6. Cultural heritage makes a significant contribution to the preservation of cultural diversity and fosters tolerance for other cultures [9].

\section{PROBLEMS WITH THE PROTECTION OF THE IMMOVABLE CULTURAL HERITAGE}

In recent years, serious problems have arisen for the immovable cultural heritage of Bulgaria, which create a precondition for the loss of part of the cultural history, for the erasure and replacement of the authentic appearance of a number of sites. The reasons for this vary and can be divided into the following groups:

\subsection{First group - administrative and organizational problems}

The national system for protection of cultural heritage includes a number of bodies and structures at national and local level. According to Art. 4 of the Cultural Heritage Act, responsible for the implementation of the state policy for protection of the cultural heritage are the Minister of Culture in cooperation with the respective competent state and municipal bodies, the Holy Synod of the Bulgarian Orthodox Church and the central leaderships of other 
registered religions and civil society. The same law provides for the establishment of a National Institute for Immovable Cultural Heritage (NIICH), which is a state cultural institute of national significance and carries out activities in the field of protection of immovable cultural heritage, including research and exploration of immovable cultural heritage. This institute assists the Minister of Culture in exercising his powers to implement the state policy in the field of protection of immovable cultural heritage. The Ministry of Culture employs an Inspectorate for Protection of Cultural Heritage. One of the functions of this inspectorate is control over the observance of the requirements of the Cultural Heritage Act and of the acts issued on its basis, related to the territorial protection of immovable cultural values (Article 15 of the Cultural Heritage Act). At local level, the mayors of the municipalities and the municipal councils are charged with the functions of protection and maintenance of these sites. All these at first glance create the impression of a well-established administrative security of the system for protection of immovable cultural heritage. There is some decentralization, but the system is still largely centralized. Proof of this is the lack of territorial structures of the Ministry of Culture and the National Institute for Immovable Cultural Heritage (the Cultural Heritage Act provides for the possibility of creating territorial structures of National Institute for Immovable Cultural Heritage, but such are currently missing - author's remark). This hinders the performance of the functions and tasks of the institute, as well as the administrative service of individuals and legal entities.

\subsection{Second group - strategic and regulatory issues}

Art. 2 of the Law on Protection and Development of Culture provides for the adoption of a National Strategy for the Development of Culture for a period of 10 years [10]. It was only in 2019 that a draft Strategy for the Development of Bulgarian Culture 2019-2029 was developed, in which attention was paid to all cultural areas. Given the specifics of the immovable cultural heritage, the question arises why no separate strategy has been developed for its preservation. A positive moment is the creation of a Strategic Plan for the development of cultural tourism, which pays attention to the importance of real estate for the development of cultural tourism. The latter was adopted in 2009 , which brings to the fore the issue of its updating. With regard to the statutory matter in the field of immovable cultural heritage, it should be noted that the provisions of the conventions of UNESCO and the Council of Europe are largely taken into account in the national legislation for the protection of immovable cultural heritage. The protection of the immovable cultural heritage is also paid attention to in Art. 23 of the Constitution of the Republic 
of Bulgaria, which states that the state takes care of the protection of the national historical and cultural heritage [11]. However, an integrated model for its adequate strategic management has not yet been developed. Conservation and management plans (CMPs), as well as an integrated conservation plan, have not yet been developed by the relevant authorities [12]. There are still no explicit regulations for assessing the impact of infrastructure and development projects on the immovable cultural heritage. The activity of monitoring the immovable cultural heritage is also limited by statutory acts. This makes it difficult to exchange information on the condition, functions, responsibilities, and to take adequate measures for the protection of these sites.

\subsection{Third group - financial problems}

Art. 71 of the Cultural Heritage Act states that the owners, concessionaires and users of immovable cultural property are obliged to take the necessary care for their protection, preservation and maintenance in good condition. These concerns are associated with a significant amount of financial resources, which are not always available to the owners, concessionaires and users of immovable cultural sites. On a positive note, the Local Taxes and Fees Act provides for an exemption from real estate tax on buildings of cultural value when they are not used for commercial purposes [13]. However, this is extremely insufficient, given the significant maintenance costs of these sites. In our country, flexible financial instruments are not applied, such as the leasing of cultural real estate. Another problem are the insufficient funds for protection of the sites of the immovable cultural heritage, which are provided in the budget of the country. The budget of the Ministry of Culture for 2021 is BGN 245 million, and BGN 27, 292, 900 have been set aside for policy in the field of protection of movable and immovable cultural heritage.

\subsection{Fourth group - problems related to human resources}

The lack of human resources is one of the significant problems for the preservation of the immovable cultural heritage. Table 1 presents data on the number of employees in the specialized administration of the National Institute for Immovable Cultural Heritage.

It is clear from the data that one employee at the institute is responsible for over 1000 sites, which means a significant amount of work. According to the Audit Report for the performed audit of the implementation of "Preservation and maintenance of architectural heritage sites in urban environment" for the period 01.01.2015-30.06.2018 some of the activities are not performed and 
Table 1. Number of sites in the National Register of immovable cultural values and number of employees in the specialized administration of the National Institute for Immovable Cultural Heritage

\begin{tabular}{|l|c|c|c|c|}
\hline Indicators & 2015 & 2016 & 2017 & 2018 \\
\hline $\begin{array}{l}\text { Number of sites in the National Register of } \\
\text { immovable cultural values }\end{array}$ & 39141 & 39150 & 39135 & 39667 \\
\hline $\begin{array}{l}\text { Number of employees in the specialized admin- } \\
\text { istration of the National Institute for Immov- } \\
\text { able Cultural Heritage }\end{array}$ & 37 & 35 & 34 & 34 \\
\hline Average number of sites per employee & 1058 & 1119 & 1151 & 1167 \\
\hline
\end{tabular}

Source: Audit report No. 0300100418 for performed audit of the implementation of "Preservation and maintenance of architectural heritage sites in urban environment" for the period 01.01.2015-30.06.2018 [14].

another part of them is not performed in full or is delayed [14]. Administrative activity (preparation of reports and opinions) predominates and takes a very large part of the time and effort of employees. Another significant problem is the lack of certified appraisers of immovable cultural property. Although there is a specific legislation related to the valuation of such sites, in the Public Register of Independent Appraisers in Bulgaria there are no persons with legal capacity to assess immovable cultural property [15].

\subsection{Fifth group - problems related to replacement technology}

According to St. Vekov in recent years there has been a lasting process that can be defined as a replacement technology [16]. This includes deliberate mismanagement of immovable cultural heritage sites and their destruction and self-destruction, as well as the destruction of existing immovable cultural heritage sites. The legislation provides a mechanism for forcing the owners to keep the objects of the immovable cultural heritage in good condition, but it is almost not applied. A problem related to the technology of replacement is the complete or partial destruction of buildings - architectural monuments, and their rebuilding on the model of the original. In the latter case, there is a replacement of the authentic architecture due to depreciation, as the new restoration of the building is far from the original and replacement of the authentic architecture as a result of renovation (See Figs 1 and 2). 


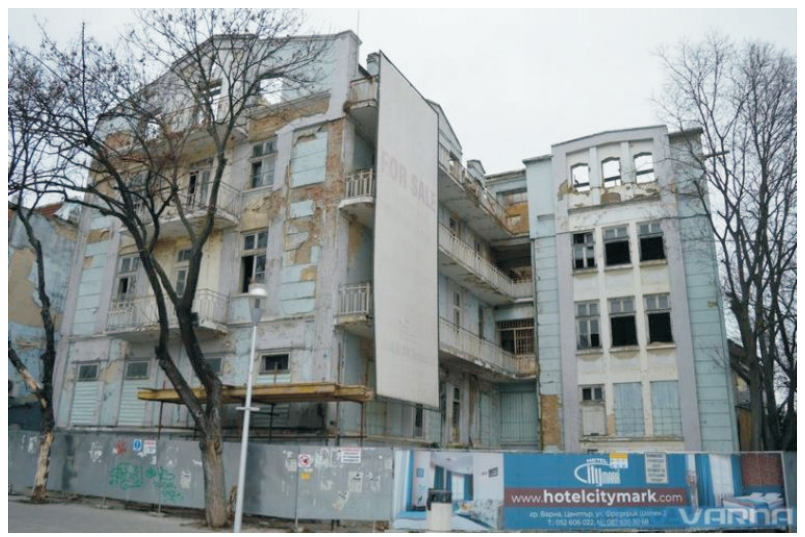

Fig. 1. Hotel "Imperial" - before the renovation Source: https://novavarna.net

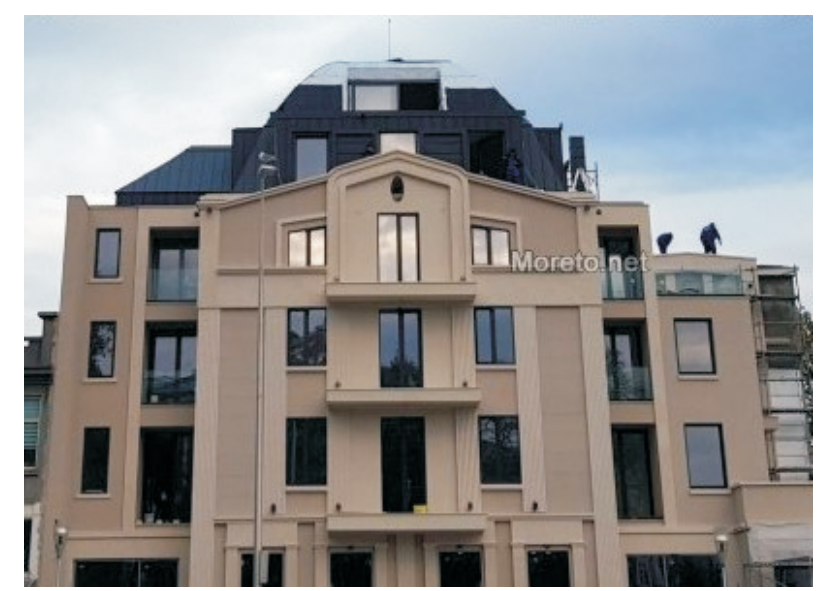

Fig. 2. Hotel "Imperial" - after the renovation Source: https://www.moreto.net

\subsection{Sixth group - social problems}

Vandalism and criminal negligence against immovable cultural heritage sites are not an isolated phenomenon. The damage inflicted on them is permanent, significant, and in some cases irreparable. Examples of this are numerous - the tobacco warehouses in Plovdiv, the Royal Stables, the Double House and the Sugar Factory in Sofia, the building of the former Sofia Bank in Varna and others. Architectural monuments, "decorated" with graffiti, can be seen in many Bulgarian cities. There is also insufficient public activity on 
the issues of protection of the immovable cultural heritage. There is also a low level of public awareness about the importance of cultural heritage. However, we cannot fail to note that some steps have been taken in terms of promoting the immovable cultural heritage with the emergence of associations such as Taliana (the Pound) (Varna), Kapana (the Trap) (Plovdiv), etc.

\section{CONCLUSION}

The present study does not claim to be exhaustive. It outlines possible guidelines for further, more in-depth research on the problems of the preservation of the immovable cultural heritage, with a view to supporting the theory and practice in this field. Solving these problems is not a one-time act, but a continuous and long-term process, which is the commitment of various participants - government agencies, municipal structures, religious institutions, owners and users. The joint and timely efforts of all stakeholders will contribute to the preservation of the physical authenticity of immovable cultural values, to the sustainable development of the urban environment and will provide new possibilities for the development of cultural tourism.

\section{REFERENCES}

[1] Convention for the Protection of the Architectural Heritage of Europe, Grenada (1985) (Online) (2021-06-08), Accessed: https://rm.coe.int/168007a087.

[2] Convention for the Protection of Cultural Property in the Event of Armed Conflict with Regulations for the Execution of the Convention (1954) (Online) (2021-06-08), Accessed: http://portal.unesco.org/en/ev.phpURL_ID $=13637 \&$ URL_DO=DO_ TOPIC\&URL_SECTION=201.html.

[3] European Cultural Convention (1954) (Online) (2021-06-08), Accessed: https: //rm.coe.int/CoERMPublicCommonSearchServices/DisplayDCTMContent? documentId=090000168006457e, Accessed 03/04/2020.

[4] Law on Cultural Heritage, Prom. State Gazette (2009) no. March 19, (Online) (2021-06-08), Accessed: https://www.lex.bg/laws/ldoc/2135623662.

[5] International Charter for the Conservation and Restoration of Monuments and Sites (1964) (Online) (2020-10-10), Accessed: http://icomosbg.org/filebank/att_82.pdf.

[6] The Strategic Plan for the Development of Cultural Tourism (2009) (Online) (2021-06-08), Accessed: http://www.strategy.bg/StrategicDocuments /View.aspx?Id=573.

[7] National Concept for Spatial Development 2013-2025 (2020) (Online) (2021-0608), Accessed: https://www.eufunds.bg/bg/oprd/node/4554. 
[8] Council Conclusion of 21 May 2014 on Cultural Heritage as a Strategic Resource for a Sustainable Europe (2014) (Online) (2021-06-08), Accessed: https://eurlex.europa.eu/legal-content/BG/TXT/?uri=CELEX:52014XG0614(08).

[9] E. Dracheva, Problems of Preservation of UNESCO Cultural Heritage Sites in Russia and Abroad, Russian Regions: A Look into the Future (2016) 2 (7) (Online) (2021-06-08), Accessed: https://cyberleninka.ru/article/n/problemysohraneniya-obektov-kulturnogo-naslediya-yunesko-v-rossii-i-za-rubezhom (access date: 24.08.2021.

[10] Law on Protection and Development of Culture, Prom. State Gazette (1999) 50 of June 1, (Online) (2021-06-08), Accessed: https://www.lex.bg/laws/ldoc/ 2134664704

[11] The Constitution of the Republic of Bulgaria (1991) (Online) (2021-06-08), Accessed: https://www.parliament.bg/bg/const.

[12] M. Krastev, Guidelines for the Development of the Immovable Cultural Heritage on the Territory of Sofia Municipality, Journal Real Estate Property and Business, Sofia (2018) 2 58-69, ISSN 2603-2767.

[13] Local Taxes and Fees Act, Prom. State Gazette (1997) 117 of December 10, (Online), (2021-06-08), Accessed: https: //www.lex.bg/laws/ldoc/2134174720.

[14] Audit report No. 0300100418 for performed audit of the implementation "Conservation and for Urban Development", Sofia, Space - Society - Economy (2019) 46.

[15] The Public Register of Independent Appraisers in Bulgaria (Online) (2021-0608), Accessed: http://public.ciab-bg.com/index.php?action=registrar\&branch $=\&$ reg_type $=\&$ account_type=personal\&knob_membership=\&name $=\&$ cert_type $=2 \&$ address_city $=\&$ cert_num $=$.

[16] St. Vekov, Where Is the Immovable Cultural Heritage of Varna Moving, Bulletin of the Union of Scientists, Varna (2014) 144-154.

Received September 01, 2021 